\title{
Environmental safety of green construction and requirements of urban planning legislation
}

\author{
Elena Voskresenskaya ${ }^{1,},{ }^{*}$ Lybov Vorona-Slivinskaya ${ }^{2}$ and Sergey Panov $^{2}$ \\ ${ }^{1}$ Peter the Great St.Petersburg Polytechnic University, 195251, St. Petersburg, Polytechnicheskaya \\ str., 29, Russia \\ ${ }^{2}$ Saint Petersburg State University of Architecture and Civil Engineering, 190005, St. Petersburg, 2nd \\ Krasnoarmeyskaya St., 4, Russia
}

\begin{abstract}
The vector that defines the strategy of innovative development of the construction industry in Russia consists in providing conditions for increasing labor productivity, reducing energy intensity and prime cost of construction process by means of introducing new institutional mechanisms that allow directing the development of the construction complex to the implementation of green construction (ecological construction) investment projects. Today, the conditions for performing green construction as an innovative and energy-efficient solution of environmental management problems are being provided in Russia taking into account modern environmental requirements. The article discusses some problems and issues of green construction, considering architecture and construction areas that are aimed at erection and operation of buildings with soft impact on the nature. In order to ensure environmental safety, the effectiveness of elaboration and implementation of investment projects for green construction should be substantiated taking into account the ecological-and-economic model of the life cycle based on the subjectoriented approach. The present scientific article defines the state and trend of green construction development in the investment-and-construction sector, analyzes environmental safety and methods of creating the innovative green building development platform. The authors recommend developing a methodological outfit to optimize the interaction of economic entities of green construction. The optimization will help to assess the effectiveness of improving the innovative green building platform and the level of environmental safety.
\end{abstract}

\section{Introduction}

The May $30^{\text {th }}, 2016$ report of the Ministry of Construction, Housing and Utilities of the Russian Federation «On the development of the construction complex and improving urban planning» describes the strategy for the innovative development of the construction industry with a focus on energy-saving technologies and innovation at all stages of the life cycle of a construction project. In recent years, Russian government creates conditions for the implementation of ecological construction as an innovative and energy-efficient

\footnotetext{
*Corresponding author: elenvoskr@mail.ru
} 
solution to the problems of environmental management, taking into account modern environmental requirements. In the ecological-economic model of the life cycle of a "green" building (GOST R ISO 9000 - 2015), the quality of a project directly depends on the degree of innovation and innovativeness of both products and processes at the stages of design, construction and operation.

If something can become the basis for sustainable competitiveness of a construction company engaged in green construction, it is only innovations. The decreasing opportunities to use traditional resources for economic growth bring to the forefront the intensification of innovation activities as one of the factors for the successful functioning and development of construction enterprises. The introduction of innovative elaborations in the development of ecological construction largely depends on the effective interaction of the subjects at all stages of the life cycle of the construction project.

In order to improve competitiveness and increase the level of environmental safety of enterprises of the investment and construction complex, it is necessary to determine the backup points for the growth of innovation in finished construction products. One of these areas is innovation activities aimed at implementation of ecological construction projects with taking into account the ecological-economic model of the building's life cycle.

Today the problem of the complexity of transformations associated with the development of green building does not have an integrated and methodologically sound approach; therefore, there is a practical significance and relevance of this research topic. The fragmentation and a certain inconsistency of the theoretical prerequisites for the substantiation of the innovative basis of green construction indicate the theoretical and scientific need for a targeted study of this problem. The following scientists have elaborated scientific and methodological foundations for the development of high-quality green construction: G. Ryabinin, E. Kulikova, N. Kerro, R. Fokov, I. Yazhlev [1-5]. The authors of the present paper have also dedicated their works to the issue of systematization of institutional basis for innovative development of green construction [6-12].

The analysis of scientific, regulatory and methodological literature on the problems of green construction indicates the absence of a generally accepted strategy for its development and shows the gaps in the legislation.

\section{Materials and Methods}

Today green construction is the most innovative segment of the construction industry, involving all available types of innovations. The formation of the innovation infrastructure of green construction that is directly related to the need of developing and improving the institutional framework will contribute to the growth of competitiveness of construction companies and enterprises interconnected with the construction industries. Green construction in Russia is practically starting out, but demand in it grows in accordance with the generally accepted tendency of increase in energy efficiency and overall development. The mainstreaming of green construction processes should be based primarily on the optimization of the innovation platform, which is reasoned by innovative nature of the development process of this type of construction. An innovative green construction platform can be presented as a system of interconnections of business entities (including investors, customers, developers, contractors and users of capital investment projects) involved in the implementation of innovative environmental solutions in construction. Such interaction is based on the principles of collective actions formed by the legal framework, ecological culture and organizational and economic mechanisms of all participants of the innovation process at each stage of the ecological and economic model of the building life cycle. 
The aim of the study is to provide methodological support for the effective development of ecological construction based on innovations, to identify ways of increasing the level of environmental safety in the construction sector and to improve urban planning legislation. The authors used regulatory and methodological documents in the field of construction and innovation, the legislation of the Russian Federation and its constituent entities, statistical materials, results of empirical researches and expert assessments as the information basis for the study.

\section{Results}

The authors assume that the most innovatively promising segment of construction industry is the sustainable development of green construction, which creates and borrows innovations of all types. Green construction has two fundamental characteristics: ensuring the conditions for a healthy human life and minimizing the human impact on the environment. The mentioned characteristics are virtually supplemented by a number of other criteria at different levels of agglomeration, forming the content of the concept of green construction.

The fundamental feature of green construction is innovativeness. Green construction creates an ecological living environment by means of introducing and developing various types of innovations that make possible the development of environmental technologies providing resource efficiency, zero waste and environmental protection. Innovations in their turn are impossible without a specific institutional framework, provision of the economic security of legal norms and interactions that form the innovation infrastructure. Thus, the development of innovation infrastructure influences ecological technologies and their development level by direct or indirect ways. Switching the economy to the innovative basis without entailing serious consequences demands changes in the culture of consumer consciousness with a focus on meeting individual needs. It is the need that can be realized based on the concept of green construction with the use of a subject-oriented approach at all stages of the building life cycle.

From the concept of the National Innovation System, as well as from the provisions of the network effect theory, the conclusion can be made that the basis for the development of green construction is its innovation platform. Such an innovation platform implies a set of network interactions of entities, united by the aim of cooperative activities for achieving the effective development and implementation of the innovation process of green construction. The infrastructure (constituent entities and their economic interrelations), standards and regulations of cooperation (town planning legislation, regulatory and technical documentation, standards, cooperation culture and traditions) constitute the innovation platform. The innovative green construction platform is not just a number of companies performing certain functions, but a system of interrelations between these entities during the implementation of innovative environmental standards in design, construction and operation (ISO 14000, BREEAM, LEED, etc.) based on the principles of cooperation.

Therefore, the provisions comprised in the Conception of developing the construction industry up to 2030, which points out insufficiently coordinated actions of the main participants of the innovation process in construction (the government, business, selfregulating organizations, development institutes, industry research centers and educational institutions) are particularly relevant. 


\section{Discussion}

Today problems of environmental safety are essential for the humanity. Anthropogenic factors of construction processes certainly adversely affect the environment. The most serious impact on the ecosystem is exerted by industrial wastes entering the external environment in forms of gases, fumes, solid wastes, water discharges; waste of power and thermal stations; household waste. The impossibility of recycling such construction waste is one of the most important problems. The problem of managing construction waste is not paid with due attention in the overwhelming majority of the constituent entities of the Russian Federation. The central region of Russia is an exception, because regulatory documents concerning the treatment of construction and demolition waste have already been developed there. In addition, such regulations propose ways to resolve problems arising when controlling construction waste.

It results in another problem of ensuring environmental safety in construction: the problem of insufficient regulatory control of this type of activity. Despite the fact that Russia has the Town Planning Code, which was supposed to regulate all issues related to the construction, the norms concerning environmental safety in construction do not have a self-contained array and are disparately scattered across the entire regulatory framework.

Table 1 provides information on the commissioning of buildings in Russia.

Table 1. Commissioning of buildings, certain production capacities, residential houses, social and cultural facilities in Russia.

\begin{tabular}{|c|c|c|c|c|c|}
\hline & 2000 & 2010 & 2014 & 2015 & 2016 \\
\hline $\begin{array}{l}\text { Buildings, total, } \\
\text { thou. } \\
\text { including: }\end{array}$ & 119.7 & 216.5 & 304.2 & 306.4 & 278.3 \\
\hline residential & 110.8 & 201.7 & 283.0 & 286.1 & 259.5 \\
\hline $\begin{array}{l}\text { non residential } \\
\text { of which: }\end{array}$ & 8.9 & 14.8 & 21.2 & 20.3 & 18.8 \\
\hline - industrial & 2.2 & 2.7 & 3.4 & 3.1 & 2.9 \\
\hline - agricultural & 1.2 & 1.8 & 2.3 & 2.5 & 2.7 \\
\hline - commercial & 1.9 & 4.4 & 7.9 & 7.2 & 6.1 \\
\hline - administrative & $\ldots$ & 0.8 & 1.4 & 1.3 & 1.2 \\
\hline - educational & 0.6 & 0.5 & 1.1 & 1.2 & 0.7 \\
\hline - health-care sector & 0.7 & 0.7 & 0.7 & 0.8 & 0.7 \\
\hline - other & 2.3 & 3.9 & 4.4 & 4.2 & 4.5 \\
\hline $\begin{array}{l}\text { Gross volume of } \\
\text { buildings, total, mln. } \\
\mathbf{m}^{2} \\
\text { including: }\end{array}$ & 172.4 & 397.4 & 317.8 & 622.8 & 608.5 \\
\hline residential & 131.6 & 271.8 & 404.4 & 415.7 & 400.4 \\
\hline $\begin{array}{l}\text { non residential } \\
\text { of which: }\end{array}$ & 40.8 & 125.6 & 213.4 & 207.1 & 208.1 \\
\hline - industrial & 13.1 & 40.7 & 55.1 & 48.8 & 45.5 \\
\hline - agricultural & 4.8 & 14.0 & 24.5 & 27.3 & 34.7 \\
\hline - commercial & 3.7 & 32.0 & 70.5 & 72.0 & 65.4 \\
\hline - administrative & $\cdots$ & 6.4 & 11.2 & 10.0 & 9.6 \\
\hline - educational & 6.7 & 8.2 & 17.1 & 19.5 & 14.8 \\
\hline - health-care sector & 5.2 & 5.9 & 3.5 & 4.0 & 4.7 \\
\hline - other & 7.3 & 18.4 & 31.5 & 25.5 & 33.4 \\
\hline $\begin{array}{l}\text { Gross floor area of } \\
\text { buildings, total, mln. } \\
\text { m }^{2}\end{array}$ & 44.7 & 91.5 & 138.6 & 139.4 & 135.8 \\
\hline
\end{tabular}




\begin{tabular}{|l|r|r|r|r|r|}
\hline including: & & & & & \\
\hline residential & 36.4 & 70.3 & 104.4 & 106.2 & 103.4 \\
\hline non residential & 8.3 & 21.2 & 34.2 & 33.2 & 32.4 \\
of which: & & & & & \\
- industrial & 2.0 & 4.3 & 5.2 & 4.8 & 4.6 \\
- agricultural & 1.2 & 3.3 & 4.6 & 5.1 & 5.8 \\
- commercial & 0.9 & 5.4 & 12.0 & 11.6 & 10.2 \\
- administrative & $\ldots$ & 1.5 & 2.5 & 2.1 & 1.9 \\
- educational & 1.5 & 1.8 & 3.9 & 4.5 & 3.3 \\
- health-care sector & 1.2 & 1.4 & 0.8 & 0.9 & 1.1 \\
- other & 1.5 & 3.5 & 5.2 & 4.2 & 5.5 \\
\hline
\end{tabular}

In 2017, 272.6 thousand buildings were commissioned. Their total construction volume amounted to 599.4 million square meters; the total area was 137.3 million square meters. Of the buildings commissioned in 2017, residential buildings topped 93.1\% (in 2016, 93.3\%). In $2017,1,139.0$ thousand new apartments with a total area of 79.2 million square meters were built on the territory of the Russian Federation at the expense of all sources of financing, which is respectively lower than in 2016 by $2.4 \%$ and $1.3 \%$. Table 2 provides information on the work scope performed by the type of activity «Construction» in Russia for 2016-2017.

Table 2. The work scope performed by the activity type "Construction" in Russia for 2016-2017.

\begin{tabular}{|c|c|c|c|}
\hline \multirow[t]{2}{*}{ Constituent entity } & \multirow{2}{*}{$\begin{array}{c}2016, \mathrm{mln} \\
\text { rubles }\end{array}$} & \multicolumn{2}{|c|}{2017} \\
\hline & & mln. rubles. & $\begin{array}{l}\% \text { to } \\
2016\end{array}$ \\
\hline Totally in Russia & 7204235.0 & 7545912.3 & 98.6 \\
\hline Central Federal district & 1842118.7 & 1930833.1 & 99.2 \\
\hline Northwestern Federal district & 1154849.1 & 1093156.2 & 87.8 \\
\hline Southern Federal district & 555031.1 & 628320.6 & 106.2 \\
\hline North Caucasus Federal district & 271914.1 & 290314.4 & 102.4 \\
\hline Volga Federal district & 1307540.6 & 1289864.9 & 93.9 \\
\hline Ural federal district & 854442.6 & 871637.7 & 98.8 \\
\hline Siberian Federal district & 789889.4 & 788363.4 & 92.9 \\
\hline Far Eastern Federal district & 428416.8 & 495687.2 & 109.2 \\
\hline
\end{tabular}

Significant decline in housing construction compared to 2016 is observed in the Omsk region - by $40.7 \%$, in the Novgorod region - by $36.0 \%$, in the Jewish autonomous region by $33.6 \%$. In 2017, in 4 constituent entities of the Russian Federation, the volume of commissioned housing increased by more than $25 \%$ compared to 2016 , of which in the Republic of Crimea - by 2.9 times, Ivanovo Region - by 1.9 times, Chukotka Autonomous region -1.7 times, the Republic of Kalmykia - 1.4 times.

In 2017, individual developers commissioned 242.7 thousand residential buildings with a total area of 33.0 million square meters, which is more than in 2016 by $3.8 \%$. In addition, the share of individual housing construction of the total amount of residential buildings commissioned increased and amounted $41.6 \%$ in 2017 against $39.6 \%$ in 2016.

Among the constituent entities of the Russian Federation in 2017, the largest volumes of housing construction were performed in the Moscow region, where the commissioned housing amounted $11.5 \%$ of the total area commissioned in Russia, in Krasnodar region $6.0 \%$, Moscow $-4.3 \%$, St. Petersburg $-4.5 \%$, the Republic of Bashkortostan $-3.1 \%$, the Voronezh Region $-2.1 \%$, the Republic of Tatarstan - 3.0\%, the Rostov Region $-2.9 \%$, the Novosibirsk Region $-2.2 \%$, the Leningrad Region $-3.3 \%$, Sverdlovsk Region $-2.7 \%$, the Republic of Dagestan $-2.5 \%$, the Samara region $-2.3 \%$. Cumulatively, in these regions of the Russian Federation, more than half of the total housing area commissioned in Russia was built. 
In accordance with international standards of green construction, certification of key projects has become an integral part of such large landmark projects as «Sochi-2014», FIFA-2018 stadiums, Skolkovo Innovation Centers, Expo 2017, «Smart City» in Kazan and others. Moscow and the Moscow Region account for $60 \%$ of the total number of certified projects. St. Petersburg ranks second with 18 objects: 7 by BREEAM and 11 by LEED, and Sochi ranks third with 7 certified buildings.

Complication of the situation in the environment, global environmental pollution and global warming become the incentive for the operational development of green construction. The main aim of the industry under consideration is to reduce the consumption of energy and material resources within the whole life cycle of a building from choosing a site to its demolition and to enhance comfortable conditions of the internal environment by means of using green technologies.

\section{Conclusions}

Today, environmental innovation solutions used in the construction industry are becoming increasingly popular. Green building is a promising direction of the construction industry. The prevalence of «green building» erection is caused by high performance characteristics that meet international environmental standards for construction. To date, there are the latest environmental developments that help construction companies to start elaborating large-scale projects of individual and public «green buildings».

The problem of insufficient regulatory control of this activity type restrains the development of green construction in Russia. To eliminate such a legislation gap, there should be developed a system of engineering and environmental support for the construction complex and for the functioning of all construction projects. The legal rules are formed due to the timely and rapid development of green construction standards, clearer mechanisms for coordinating works on state order, as well as the possibility of using innovative materials and technologies that do not cause obstructions from the side of expertizing bodies.

Further development of the present topic can be focused on working out methods for estimation of economic and social effect of green building projects, as well as on specification of the subject composition for the innovation platform and on clarification of the specifics and criteria for the effectiveness of interaction between the subjects.

\section{References}

1. A. Ryabinin, Applied ecology in road construction, 144 (2009)

2. E. Kulikov, A methodology for the selection of ecologically safe technologies of underground construction (2016)

3. N. Kerro, Environmental safety in construction. Risks and pre-project studies (2017)

4. R. Fokov, Ecological reconstruction and improvement of urban environment (2015)

5. I. Yazhlev, The Environmental rehabilitation of the polluted industrial and urban areas (2015)

6. E.Voskresenskaya, V. Snetkov, A. Tebryaev, Z.n Askarov, MATEC Web of Conferences 106, 08055 (2017)

7. E. Voskresenskaya, V. Snetkov, A. Tebryaev, V E3S Web of Conferences 33, 03051 (2018) doi.org/10.1051/e3sconf/20183303051

8. E. Voskresenskaya, L. Vorona-Slivinskaya, V E3S Web of Conferences 33, 03052 (2018) https://doi.org/10.1051/e3sconf/20183303052 
9. E. Voskresenskaya, D. Mokhorov, A. Tebryaev, Matec web of conferences 170, 01058 (2018) DOI https://doi.org/10.1051/matecconf/201817001058

10. E. Voskresenskaya, N. Zhilskiy, E. Shariapova, Matec web of conferences 170, 01057 (2018) DOI https://doi.org/10.1051/matecconf/201817001057

11. P.K. Sun, L. Vorona-Slivinskaya, E. Voskresenskaya, IOP Conference Series: Earth and Environmental Science 90 (2017) https://doi.org/10.1088/1755-1315/90/1/012073

12. E. Voskresenskaya, L. Vorona-Slivinskaya, S. Panov, MATEC Web of Conferences 193, 02025 (2018) doi.org/10.1051/matecconf/201819302025 